\title{
Comparison of Live and Removal Methods to Estimate Small Mammal Densities
}

\author{
Del T. SCOTT, Clive D. JORGENSEN \& H. Duane SMITH
}

\begin{abstract}
Scott D. T., Jorgensen C. D. \& Smith H. D., 1978. Comparison of live and removal methods to estimate small mammal densities. Acta theriol., 23, 8: 173-193 [With 6 Tables \& 5 Figs.].

Populations of small mammals were simulated and samples collected from them to determine comparative strengths and weaknesses of the population estimates most commonly used. All experimental samples were collected with population parameters known, each being modified to assess how the estimators respond to presumed population behavior of small mammals. Population parameters we modified were densities, activity ranges and birth and death rates. These parameters were adjusted to simulate presumed extremes for naturally occurring populations. Eighteen experiments included densities remaining constant, and 27 with birth and/or death resulting in varying densities. When all assumptions of population stability and uniformity were satisfied for live trapping, Hayne's and the $E M-2$ estimates were the most reliable, although Lincoln's estimate was also reasonably effective. Results of this study suggest the $E M-2$ estimate is best when livetrapping is required and Smith's assessment line estimator usually provides reliable estimates when kill-traps are used but the latter varied widely as population numbers changed during the trapping period.

[Dept. Zool., Brigham Young Univ., Provo, Utah 84602, USA].
\end{abstract}

\section{INTRODUCTION}

Small mammal ecologists repeatedly face the problem of assessing which of numerous population estimators they should use to satisfy their specific needs.

A choice of estimators should be based on the accuracy of the estimate and its attendent population assumptions: i.e. population stability, birth, death, dispersal etc. Assessing how different estimators react to changes in the population variables requires a comparative evaluation of the same data using different estimators, and can be accomplished only by sampling populations with known parameters. Problems occur that cannot be controlled or evaluated while sampling natural populations: i.e., the time necessary to gather sufficient data; the expense of equipment, man-power and sampling; and the lack of control or knowledge of the influencing population parameters. Sampling from simulated populations with varying densities, activity ranges, birth and death rates alleviates most problems and allows control of the parameters: 
thus, the conclusions reached should be reliable and valid for natural populations provided the simulation is appropriate.

Some of the recently developed sampling methods yield more information about the populations than earlier methods and provide better data for estimates; thus, there is increased interest in several new designs and their associated estimators (P elikán, 1971; Rys zkowski, 1971; Myllymäki et al., 1971; Ka ufman et al., 1971; Smith et al., 1971; Gromadzki \& Trojan, 1971; Smith et al., 1972; Jorgensen et al., 1975; Swift \& Steinhorst, 1976; C a meron, 1977).

Five designs currently of considerable theoretical importance are: (1) a design for removal trapping, that allows for computing the area of effect (S mith et al., 1971), (2) a design for capture-recapture trapping, that keeps the area of effect somewhat constant ( $\mathrm{S} \mathrm{mith}$ et al., 1972, and Jorgensen et al., 1975), (3) a design for capturerecapture trapping that population estimates without an area estimate (Jolly, 1965; S e b e r, 1965), (4) a design for capture-recapture trapping that removes captured animals while completing the trapping effort and releasing them later where they were caught after all collecting was completed (Cameron, 1977), and (5) a design for capture-recapture trapping which allows for computing the area of effect ( $\mathrm{S}$ wif $\mathrm{t}$ \& Steinhorst, 1976). Ideally, these designs should yield the necessary information about the population densities despite possible effects of the trapping, i.e. animals that are killed with removal trapping and animals that become trap-happy or trap-shy with capture-recapture methods, etc. This study provides analyses of data collected from simulated populations and applied to estimators associated with S $\mathrm{m}$ i th's et al. (1971) and Jorgens en's et al. (1975) field designs, that help identify the strengths and weaknesses of both. Methodologies proposed by Swift \& Steinhorst (1976) and Cameron (1977) were not included since they were not available at the time the experiments were conducted.

\section{Estimators}

The similarities and differences of several commonly used estimators are demonstrated by reviewing the basic concepts and standardizing the notations. These similarities and differences are essential to review because the two estimators (Smith et al., 1971; Smith et al., 1972 and Jorgensen et al., 1975) used in this comparative study have their origins with earlier models. The simplest and most widely used estimators of live populations are based on the ratios of marked to unmarked animals in the samples (Petersen, 1896; 
Lincoln, 1930; Schnabel, 1938 and Bailey, 1952). Lincoln (1930) used the ratio $m_{i} / n_{i}$ as an estimate of $M_{i} / N_{i}$, thus $N_{i}$ was estimated with:

$$
N_{(L) i}=\frac{M_{i} \cdot n_{i}}{m_{i}}
$$

where: $M_{i}=$ the accumulated number of animals marked and released before day $i$, by definition $M_{1}=n_{1}$ and generally $M_{i}=M_{i-1}+n_{i-1}-m_{i-1}=$ the number of animals released on day $i$,

$m_{i}=$ the number of marked animals caught on day $i$, and

$n_{i}=$ the number of marked and unmarked animals caught on day $i$.

An estimator proposed by $\mathrm{H}$ a y ne (1949) for analyzing capture-recapture data uses a variation of the marked to unmarked ratio that causes the estimate to approach $N_{i}$ as the trapping days increase with less variability than $\hat{N}_{(L)} \cdot N_{i}$ is estimated with:

$$
N_{(H) i}=\sum_{k=2}^{i} n_{k} M_{k}^{2} / \sum_{k=2}^{i} m_{k} M_{k}
$$

When every animal in the population has been marked, $\boldsymbol{M}_{i-1}$ will equal $\boldsymbol{M}_{i}$ and $n_{i}$ will equal $m_{i}$, forcing $\hat{N}_{(L) i}$ equal to $M_{i}$. This is not true for $\hat{N}_{(H) i}$ because it is a weighted average of the previous trapping results.

Hayne (1949), also proposed an estimator for analyzing the data produced by removal trapping, where $N$ was estimated from the regression line $n_{i}=a+b R_{i}$. Since $a$ and $b$ can be estimated with standard regression techniques, and because $n_{i}=0$ when all the animals are removed; an estimate of $N$ was found by setting the regression equation equal to zero $\left(0=a+b R_{t}\right)$ and solving for $R_{t}$ :

$$
\hat{N}_{(H)}=R_{t}=-a / b
$$

These three estimators assume no death or migration during the trapping period. Leslie \& Chitt y $(1951)$, Leslie $(1952$ and J olly $(1963,1965)$ developed estimators that include animal survival rates. Of these, Jolly's (1965) seems to be more widely used and has been shown to react better to changes in the population ( $\mathrm{J}$ orgensen et al., 1972; and Manly, 1970). The survival rate is estimated by dividing $M_{i}^{\prime \prime}$ by $s_{i}$, which is then used as the basis for estimating the number of marked animals in the population, consequently:

$$
\hat{M}_{i}=\frac{M_{i}^{\prime} \cdot s_{i}}{M_{i}^{\prime \prime}}+m_{i}
$$

where: $s_{i} \quad=$ the number of animals released on day $\mathrm{i}$, if no animals die in the traps on day $i, s_{i}=n_{i}$,

$M_{i}^{\prime}=$ the number of animals caught and marked before day $i$, that werenot caught on day $i$, but were caught after $i$, and

$$
M_{i}^{\prime}=\sum_{k=1}^{i-1} \sum_{j=i+1}^{t} A_{k j}
$$




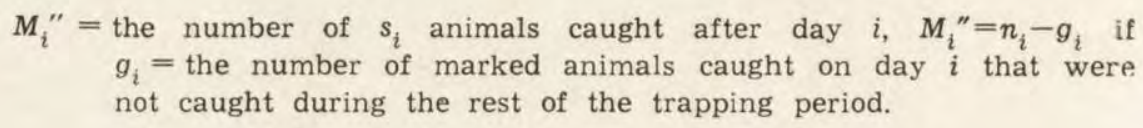

$$
g_{i}=n_{i}-\sum_{j=i+1}^{t} A_{i j}
$$

Jolly's (1965) population number is estimated by a formula similar to equation (1):

$$
N_{(J) i}=\stackrel{\hat{M}_{i} \cdot n_{i}}{m_{i}}
$$

This estimator provides population estimates that change in response to mortality, while Lincoln's and Hayne's estimators are defined for stable populations only. All estimators are somewhat robust in estimating a sgrowing " population in that their estimates provide for increases with the addition of new unmarked animals.

\section{Simulators}

Before we can adequately describe the methods used herein, it is essential that the simulation from which data are obtained be understood. Burnham \& Overton (1969), Manly (1970), and Jorgensen et al. (1972 have developed simulators and analyzed the data generated from them to gather information about various estimators. Burnham \& Overton (1969) compared estimators provided by Petersen (1896) and Schnabel (1938) with a geometric, and an approximation to the geometric for stable animal populations with different probabilities of capturing individual animals. The probabilities of capture were generated from five distributions: (1) constant $\varrho$, (2) Beta $(\alpha, \beta) \alpha>1, \beta>1$, (3) uniform $(0,2 E(p), E(p)<1 / 2$, (4) Beta $(1, \beta) \beta>1$, (5) Beta $(\alpha, 1) \alpha>1$; which were used in the simulation to determine the number of marked and unmarked animals instantaneously caught for one trapping period. Data provided by the simulator caused Burnham \& Overton (1969) to conclude: (1) Schnabel's (1938) procedure was good when the capture probabilities $(p)$ where equal for all animals, but poor when the variance of $p$ became large; (2) Petersen's (1896) estimator performed like Schnabel's, but was usually closer to the actual population size; (3) both geometric estimators had a tendency to begin far below the true population value for the first few days of trapping, then overshoot it for the next few days before eventually converging on the true value. They also hypothesized that the Beta distribution may have a wide range of applicability in the real world for assessing the probability of capturing animals.

M a n ly (1970) simulated the trapping of animal populations possessing various birth and death rates. After examining the estimators suggested by $\mathrm{F}$ is her \& Ford (1947), Jolly (1963, 1965) and Manly \& Parr (1968) he concluded that: (1) the Fisher \& Ford (1947) and Jolly (1965) estimators provided similar accuracy although Jolly's seemed to produce larger overestimates when samples were small, and the estimates tended to approximate the sample size, (2) M a n ly \& Parr's (1968) method frequently provided poor estimates with small samples and also estimated the population to be approximately equal to the sample size, 
and (3) all methods gave a similar order of accuracy when samples were large.

The simulators developed by Burnham \& Overton (1969) and Manly (1970) were used to generate data for estimations independent of a trap design. J orgensen et al. (1972) developed a simulator which provided for »catching " an animal and determining at which trap location it was caught. Their simulator also provided for sampling from a population with different capture probabilities through the night, different birth, death and dispersal rates, different activity ranges, different animal spatial distributions, and different trapping designs. The basis of this simulator was that every animal and trap had a relationship dependent on the location of the trap in the animal's activity range. The distance from the center of the activity range to any trap can be normalized by the procedure described in Burge \& Jorgensen (1972), such that when an animal is trapped or otherwise observed, one can be confident at the .95 level it will be inside a region circumscribed by an appropriate radius.

The normalized distance called $y_{i j}$, where $i=$ the animal number and $j=$ the trap number, and edensity function of the standard normal curve called $f\left(y_{i j}\right)$, were used to transform the distance into a number $\left(z_{i j}\right)$ that decreased as the distance increased with the restriction that if $y_{i j} \geqslant 1.96$, then $z_{j i}=0$. Then $z_{i j}$ was integerized by multiplying it with a constant, such that the sum of all the resulting numbers $\left(P_{i j}=\right.$ probability of capture) was less than $2^{31}-1$. Since $P_{i j}$ was greater than zero for every trap within the $95 \%$ confidence region of the activity range and zero elsewhere, it could be related directly to the probability of animal $i$ being caught in trap $j$ with:

$$
\text { probability }=P_{i j} / \sum_{s=1}^{n a} \sum_{t=1}^{n t} P_{s t}
$$

where: $n a=$ the total number of animals in the trapping area and

$n t=$ the total number of trap stations in the complete design.

Animals were caught and assigned to traps in their respective activity ranges based on the principle that the closer a trap was to the activity center the larger $P_{i j}$ would be. The percentage of animals that could be caught or were at risk per time unit per day for each class $(r / t)$ was used to determine the average number of animals caught per time unit per day. This number was the mean used by the Poisson distribution to generate the probabilities of catching $0,1,2, \ldots$, and $x$ animals. One of the points was rondomly selected, with the points having the higher probabilities also having the higher likelihood of selection. This point was used as the number of animals caught at that time unit. A random number $(R)$ was generated to cathch an animal and assign it to a trap from a uniform integer distribution, $\mathrm{O}<R<2^{31}-1$. Then the function $P_{i j} \cdot r / t$ was compared for every $i$ and $j$ until:

$$
R \leqslant \sum_{i=1}^{n a} \sum_{j=1}^{n t} P_{i j} \cdot r / t
$$

If equation (7) is not satisfied for any $i$ and $j$, a new $R$ was chosen, but when equation (7) was satisfied both the animal and trap were associated and identified

Then trap $j$ was checked to determine if it was already occupied; if occupied, 
a new $R$ was chosen and another attempt made to catch an animal and assign it to another trap.

The process of catching animals (equation 7) continued until the appropriate number of animals per time unit had been caught, then the next time unit was used to find the number of animals to be caught from those animals at risk. Animals were caught until all the time units were used, then the animals and traps in which they were caught were printed-concluding one day in the trapping period.

Objectives of this research were: (1) to empirically compare the S mith et al. (1971) estimator (hereafter $E M-R$ ) with the Jorgensen et al. (1975), Jolly (1965), Hayne (1949) and Lincoln (1930) estimators by analyzing simulated data generated from stable populations, increasing populations, decreasing populations and unstable population; (2) to compare $\mathrm{Smith}$ et al. (1971)

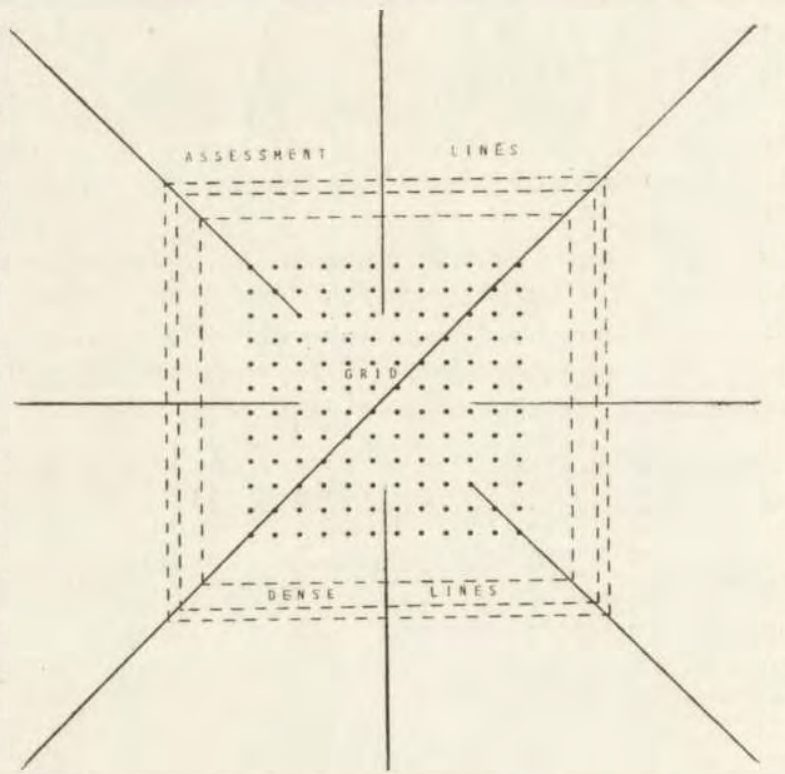

Fig. 1. Trapping design for $D S-2$ and $D S-R$. Trap spacing for the simulated data was $22 \mathrm{~m}$, and $11 \mathrm{~m}$ on the assessment lines, with the side assessment lines being $210 \mathrm{~m}$ beyond the grid.

removal design (hereafter $D S-R$ and the $\mathrm{Smith}$ et al. (1972) capture-recapture design (hereafter $D S-2$ ): and (3) to give an explanation of why and how other estimators and designs react to changes in essential population parameters.

\section{METHODS}

\section{Field Designs}

The $D S-R$ field design used a modified Standard Polish Grid ${ }^{2}$ (Fig. 1) which had been prebaited for three days, after which the animals were trapped and

2 The modified Standard Polish Grid included a $12 \times 12$ trap placement rather than the $16 \times 16$. 
removed for the next 10 days. Following this, traps from the grid were removed and eight assessment lines set and trapped for the next four days. Removal trapping of the grid was used to create a void, while trapping on the assessment lines was used to measure the size of the void. Densities were estimated by dividing the void area into the population estimated from the animals caught on the grid (S mith et al., 1971).

$D S-2$ used the modified Standard Polish Grid surrounded by at least three permeable "fences « of traps (dense-line) with the one farthest from the grid having the highest concentration (Fig. 1). The purpose of the dense-line was to measure movement, without which it is difficult to accurately estimate birth and death rates, since birth and dispersion are completely confounded. A similar statement can be made about death and dispersion. The algorithm used in this study to determine if an animal was a grid resident was to count the animal as a resident of the grid if it had been captured at least $60 \%$ of the time on the grid (as distinguished from the dense-line).

\section{Analytical Methods}

$E M-R$ was based on the $\mathrm{H}$ a y ne (1949) removal trapping estimator (equation 3) used to estimate the number of animals removed from the area affected by the grid. Plotting the accumulated captures for a trap line against distance from the grid results in a straight line, whose slope represents the rate of capture. If all the animals were removed from the sampling area, the slope would change abruptly at the edge of the sampling area and be equal to zero inside this area. There were, however, three areas of interest: area of complete removal, area of partial removal and the area of no removal. Starting at the end of the assessment lines farthest from the grid, the number of animals caught were accumulated, resulting in three regression lines defined so the residual mean square errors were minimized in:

$$
Y_{i}=\left(a_{c}+b_{c} X_{i}\right) Z_{c}+\left(a_{p}+b_{p} X_{i}\right) Z_{p}+\left(a_{u}+b_{u} X_{i}\right) Z_{u}+e
$$

where: $Z_{c}=1, z=0$, and $Z_{u}=0$ if $X_{i}$ was in the area of complete removal; $Z_{c}=0, Z_{p}=1$, and $Z_{u}=0$ if $X_{i}$ was in the area of partial removal; and $Z_{c}=0, Z_{p}=0$, and $Z_{u}=1$ if $X_{i}$ was in the unaffected area.

In should be noted that equation 8 could be written as three separate straight lines, one for each area. The algorithm used was to try all possible definitions of area, such that the error mean square of equation 8 was minimized.

The exact point of demarcation between the areas of complete and partial removal was calculated with the following equations for $X$ :

$$
\begin{aligned}
& Y_{j}=a_{c}+b_{c} X_{j} \\
& Y_{j}=a_{p}+B_{p} X_{j}
\end{aligned}
$$

The point outside of the grid along the assessment lines representing the area of complete removal was found with:

$$
X=\frac{a_{c}-a_{p}}{b_{p}-b_{c}}
$$


with $b_{c}=0$ when removal was complete. The size of the area of complete removal was estimated with $A^{\prime}=(2 X+W g)^{2}$, where $W g$ is the width of the grid. Densities were then obtained by dividing $A^{\prime}$ into the estimated population size.

$E M-2$ was based on the partitioning of marked and released animals that were not recaptured during the remaining trapping days into death, dispersal, and others. Methods for this partitioning were adequately described by Jorgense $n$ et al. (1975) and S cot t (1973); resulting in the estimate:

$$
E M-2_{i}=\frac{\left(n_{i+1}+k_{i+1}\right)}{\left(m_{i+1}+k_{i+1}\right) / M_{i}}
$$

Table 1

Estimated population densities for simulation experiments, with the populations remaining constant during sampling.

\begin{tabular}{|c|c|c|c|c|c|c|c|c|}
\hline \multirow{3}{*}{$\begin{array}{l}\text { Experiment } \\
\text { No. }\end{array}$} & \multicolumn{8}{|c|}{ Population Density Estimates } \\
\hline & \multicolumn{5}{|c|}{ Live Trapping (Grid Area $=5.86$ ha) } & \multicolumn{3}{|c|}{ Removal Trapping Densitie; } \\
\hline & $\underset{\bar{N}_{(L)}}{\operatorname{Lincoln}}$ & $\begin{array}{l}\text { Haynea } \\
\tilde{N}_{(H)}\end{array}$ & $\begin{array}{l}\text { Jolly } \\
\bar{N}_{(J)}\end{array}$ & $E M-2$ & Actual & $\begin{array}{c}\text { Estimated } \\
R M-R\end{array}$ & Actual & $\begin{array}{l}\text { Size of } \\
\text { Area, ha }\end{array}$ \\
\hline 1 & 2.22 & 2.56 & $-\mathrm{b}$ & 3.58 & 3.07 & 2.66 & 2.81 & 6.76 \\
\hline 2 & 3.24 & 3.24 & 2.24 & 2.56 & 3.07 & 2.81 & 2.97 & 6.40 \\
\hline 3 & 5.46 & 5.63 & 4.95 & 5.63 & 5.12 & 6.50 & 6.50 & 7.23 \\
\hline 4 & 5.46 & 5.97 & 5.12 & 4.61 & 5.12 & 6.36 & 6.50 & 7.23 \\
\hline 5 & 7.51 & 7.85 & 7.68 & 6.83 & 6.14 & 7.53 & 8.29 & 7.84 \\
\hline 6 & 11.60 & 8.02 & 4.10 & 5.12 & 6.14 & 7.53 & 8.29 & 7.84 \\
\hline 7 & 3.24 & 3.24 & 8.19 & 3.07 & 2.90 & 3.05 & 3.05 & 8.53 \\
\hline 8 & 3.24 & 3.07 & 3.41 & 2.90 & 2.90 & 2.89 & 3.02 & 7.95 \\
\hline 9 & 7.17 & 7.17 & 7.34 & 5.46 & 5.97 & 6.21 & 6.21 & 7.73 \\
\hline 10 & 7.17 & 7.34 & 7.00 & 4.95 & 5.97 & 5.98 & 5.63 & 8.53 \\
\hline 11 & 9.73 & 10.07 & 6.83 & 8.36 & 8.36 & 10.64 & 8.89 & 6.86 \\
\hline 12 & 9.73 & 9.73 & 7.51 & 8.02 & 8.36 & 9.60 & 9.05 & 7.29 \\
\hline 13 & 3.07 & 3.07 & 5.46 & 2.73 & 2.22 & 3.60 & 2.70 & 6.66 \\
\hline 14 & 3.07 & 3.07 & 8.19 & 3.07 & 2.22 & 2.76 & 2.62 & 7.24 \\
\hline 15 & 5.80 & 5.80 & 7.51 & 5.29 & 2.73 & 6.35 & 5.66 & 7.24 \\
\hline 16 & 4.61 & 4.61 & 4.95 & 3.92 & 2.73 & 6.12 & 5.48 & 7.84 \\
\hline 17 & 10.41 & 10.24 & 7.34 & 7.36 & 7.34 & 10.99 & 9.01 & 6.55 \\
\hline 18 & 9.56 & 9.56 & 11.60 & 7.68 & 7.34 & 10.65 & 8.74 & 6.76 \\
\hline
\end{tabular}

a These estimates are reported for the 10th day, whereas all other live trapping estimates are for the 9th.

b An estimate could not be obtained for this experiment because of incomplete data.

\section{RESULTS}

Results of these studies produced data too voluminous to completely report; consequently, only comparative data are included. $E M-2$ and other live-trapping estimates for stable populations are presented for the ninth day only, although complete data were obtained for all 10 days of trapping during each period (Table 1). Hayne's estimates are re- 
ported for the tenth day, since that represents the estimate with the most data. All experiments were replicated twice and the average used as the basis for comparison.

Population sizes for the experiments with removal trapping varied among their own replications and from those reported for the live trapping experiments - in spite of the fact that the number of animals included in each experiment was constant (Table 1). Differences between the removal and live trapping resulted from the field designs: the removal trapping area was determined as a function of results obtained from the assessment lines, while the area was fixed by the grid design for live trapping. Actual numbers of animals included in the total potential area of influence (by trapping) and their specific important parameters are reported in Table 2.

Table 2

Numbers of simulated animals and their respective home range radii included in the sampling experiments when the population remained constant during sampling.

\begin{tabular}{ccc}
\hline $\begin{array}{c}\text { Experiment } \\
\text { No. }\end{array}$ & $\begin{array}{c}\text { Number } \\
\text { onimals in } \\
\text { area of Influence }\end{array}$ & $\begin{array}{c}\text { Home Range } \\
\text { Radius, }(\mathrm{m})\end{array}$ \\
\hline $1-2$ & 100 & 30 \\
$3-4$ & 200 & 30 \\
$5-6$ & 300 & 30 \\
$7-8$ & 100 & 44 \\
$9-10$ & 200 & 44 \\
$11-12$ & 300 & 44 \\
$13-14$ & 100 & 54 \\
$15-16$ & 200 & 54 \\
$17-18$ & 300 & 54 \\
\hline
\end{tabular}

After sizes of the populations and areas they utilized were estimated, the computed densities were compared with the actual number of animals located on the grid area. Three methods were used to compare the population estimates:

1. Deviations from the actual unstandardized population size:

$$
\text { Dev }=\sum_{i=1}^{t}\left(N_{i}-N_{i}\right)
$$

2. Chi-square goodness of fit:

$$
\chi_{t}^{2} \equiv \sum_{i=1}^{t} \frac{\left(N_{i}-N_{i}\right)^{2}}{N_{i}}
$$


3. Percent relative bias ( $\mathrm{M}$ a $\mathrm{n} \mathrm{l} \mathrm{y}, 1970)$ :

$$
\% \text { bias }=\left[\sum_{i=1}^{t} \frac{N_{i}-N_{i}}{N_{i}}\right] \cdot \frac{100}{t}
$$

Although all three comparative statistics were calculated and used in the assessments of estimator accuracies, only the percent bias is presented here since it standardizes differences in experimental densities and provides comparative statistics that are easily visualized. Since only one estimate is justified for the stable populations and daily estimates are required for the unstable populations, a simplified version of the percent bias was used, $\%$ bias $=(N-N) / N 100$. This procedure also allows direct comparisons of the results.

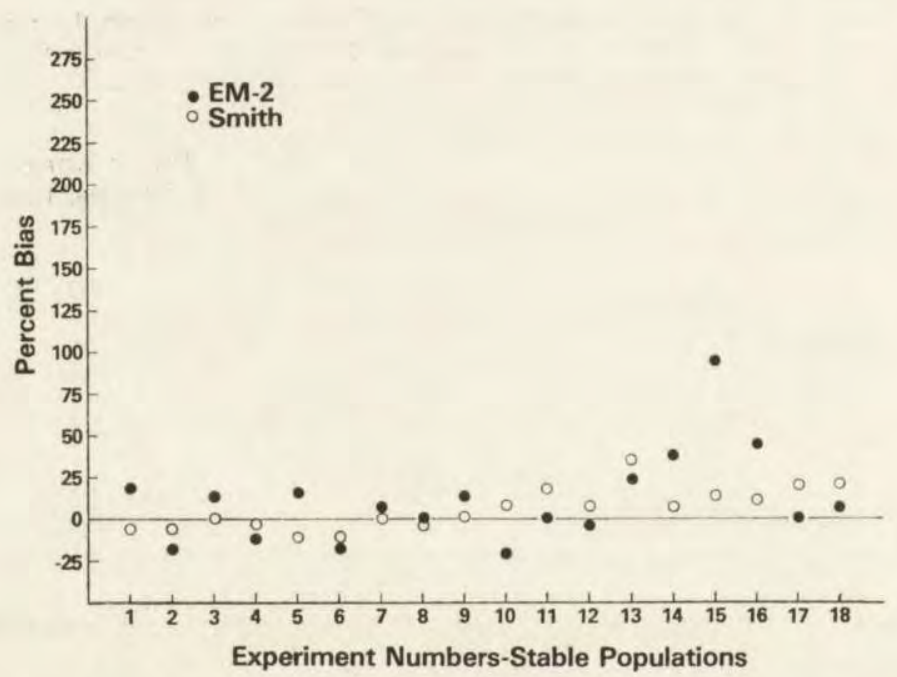

Fig. 2. Percent biases for the EM-2 (Jorgensen et al., 1975) and Smith et al (1971) estimates of the stable populations. Perfect agreement with the actua! density $=0$.

Comparative relative biases can easily be assessed from results presented in Fig. 2 and 3 for all estimates of the stable populations. These comparisons originated from Table 1 and include only the one day's estimates as indicated. Stable populations, although convenient, likely do not occur in nature; thus, additional experiments were conducted that included estimates for unstable populations. These experiments required an entirely new set of population parameters (Table 3). 
Since the populations were changing on a daily schedule, resulting from birth and/or death, a single estimate for each of the live trapping experiments was not meaningful for the unstable populations. Tables 4 and 5 provide density estimates for each trapping day included in all of the 27 experiments with unstable populations. Comparative relative biases for the unstable population experiments can be conveniently examined on Fig. 4 and 5. Standard errors provide an assessment of the variance among the 9 daily estimates for each experiment. Although daily results are provided for the live-trapping estimators, only one estimate is available when the $\mathrm{Smith}$ et al. (1971) removal-trapping method was used (Table 6).

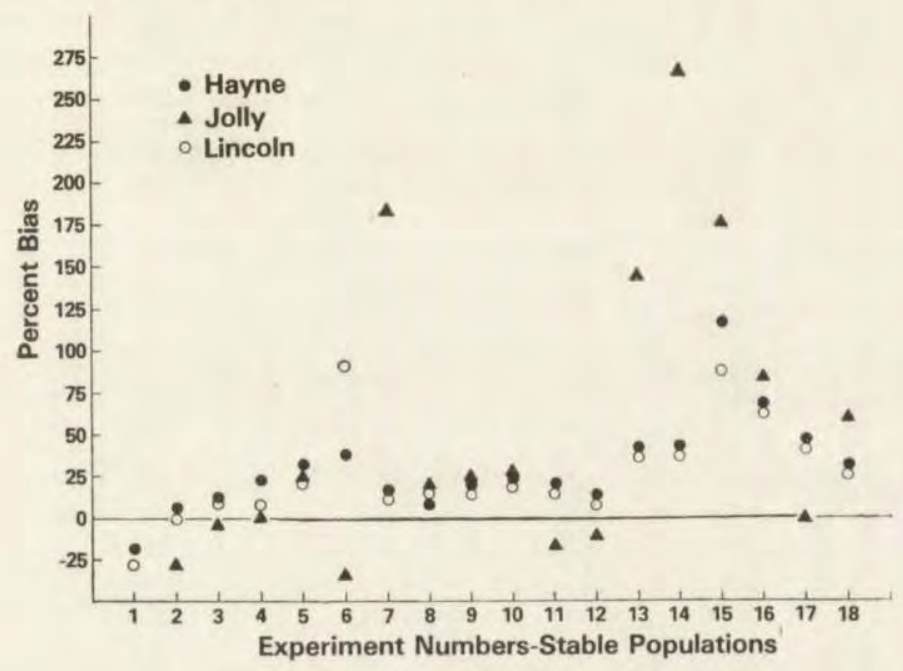

Fig. 3. Percent biases for the Ha yne (1949), Jolly (1965) and Lincoln (1930) estimates of the stable populations. Perfect agreement with the actual density $=0$.

$\mathrm{Smith}$ et al.'s (1971) results are difficult to compare with the live-trapping methods because of the varying number of comparisons required, but the percent biases on Fig. 5 are helpful, even in the absence of standard errors for the removal method.

\section{DISCUSSION}

Experiments reported in this study were designed to provide data and an understanding of how field trapping designs (DS-R, DS-L), coupled with several different estimators $\left(D M-2, N_{(H)}, N_{(L)}, N_{(J)}\right.$, and $E M-R)$ respond to trapping samples from populations with: (1) stable population sizes, (2) changing population sizes due to birth and death. (3) varying home range sizes and (4) varying densities (Table 2 and 3 ). 
Since these responses were determined for a wide range of combined population variables, their respective impacts on the estimators were assessed. These assessments were based on the assumption that any estimator should approximate $N$, thus, $(N-N)^{2}$ should be as small as possible to insure accuracy. Although the magnitude of $(\mathbb{N}-N)^{2}$ reflects comparatively how good an estimator is if the population parameters

\section{Table 3}

Population parameters for simulation in which the numbers of animals were changing (unstable) during the sampling period.

\begin{tabular}{|c|c|c|c|c|c|}
\hline \multirow{2}{*}{$\begin{array}{l}\text { Experiment } \\
\text { Number }\end{array}$} & \multicolumn{3}{|c|}{ Population Change Rates } & \multirow{2}{*}{$\begin{array}{c}\text { Initial } \\
\text { Population } \\
\text { Size }\end{array}$} & \multirow{2}{*}{$\begin{array}{l}\text { Home Range } \\
\text { Radius } \\
(m)\end{array}$} \\
\hline & $\begin{array}{l}\text { Birth } \\
\text { (b) }\end{array}$ & $\begin{array}{l}\text { Death } \\
(d)\end{array}$ & $\begin{array}{r}\text { Total } \\
(b-d)\end{array}$ & & \\
\hline 1 & .500 & .000 & .500 & 200 & 44 \\
\hline 2 & .490 & .000 & .490 & 133 & 44 \\
\hline 3 & .490 & .000 & .490 & 67 & 44 \\
\hline 4 & .490 & .072 & .418 & 133 & 30 \\
\hline 5 & .490 & .072 & .418 & 67 & 54 \\
\hline 6 & .490 & .073 & .417 & 67 & 54 \\
\hline 7 & .160 & .000 & .160 & 133 & 54 \\
\hline 8 & .160 & .000 & .160 & 67 & 30 \\
\hline 9 & .150 & .000 & .150 & 200 & 54 \\
\hline 10 & .160 & .072 & .088 & 133 & 44 \\
\hline 11 & .160 & .072 & .088 & 133 & 30 \\
\hline 12 & .150 & .072 & .078 & 200 & 44 \\
\hline 13 & .000 & .000 & .000 & 200 & 30 \\
\hline 14 & .100 & .000 & .000 & 67 & 30 \\
\hline 15 & .000 & .000 & .000 & 133 & 54 \\
\hline 16 & .000 & .072 & -.072 & 67 & 54 \\
\hline 17 & .000 & .072 & -.072 & 200 & 44 \\
\hline 18 & .000 & .072 & -.072 & 200 & 30 \\
\hline 19 & .500 & .720 & -.220 & 200 & 54 \\
\hline 20 & .500 & .720 & -.220 & 200 & 30 \\
\hline 21 & .490 & .720 & -.230 & 133 & 30 \\
\hline & .160 & .720 & -.560 & 67 & 30 \\
\hline 23 & .160 & .720 & -.560 & 67 & 44 \\
\hline 24 & .150 & .720 & -.570 & 200 & 54 \\
\hline 25 & .000 & .720 & -.720 & 133 & 54 \\
\hline 26 & .000 & .720 & -.720 & 67 & 44 \\
\hline 27 & .000 & .720 & -.720 & 133 & 44 \\
\hline
\end{tabular}

are unknown, a robust estimator is likely to persistantly provide better results. Also, the estimator should provide as much information about the population as possible. Results of this work may be used in seiecting field designs and estimators that are most appropriate for the investigator's needs.

Considerable effort has been made to assess the usefulness and accuracy of the Jolly (1965) estimator. Since first published, it 
Table 4

Densities (animals per ha) for $\mathrm{H}$ a y ne $\left(\hat{N}_{H}\right)$ and the $E M-2$ estimation methods of simulated populations in which the numbers of animals were changing during the sampling period (see Table 3 ).

\begin{tabular}{|c|c|c|c|c|c|c|c|c|c|c|}
\hline \multicolumn{11}{|c|}{ laity Estingtes for Esch Trapping Day $-y$ is in Parentheses } \\
\hline & & 2 & 3 & 4 & 5 & 6 & $\approx$ & 8 & 9 & 10 \\
\hline & & $\frac{N_{(B)} \frac{E M-2}{(N)}}{(N)}$ & $\begin{array}{c}\hat{N}_{(H)-E N-2} \\
(N)\end{array}$ & $\left.\hat{N}_{(H)}\right)_{(N)}^{-E N-2}$ & $\hat{N}_{(H)} \frac{-E M-2}{(N)}$ & $\hat{x}_{(Z)-E U-2}$ & $\hat{N}_{(H)} \frac{-E N-2}{(N)}$ & $\left.\overline{\hat{N}}_{(H I)}\right)_{(N)}^{-E N-2}$ & $\left.\vec{u}_{(I I)}\right)_{(N)}^{-E N-2}$ & 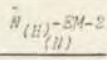 \\
\hline 2 & 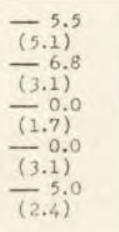 & $\begin{array}{l}(5.3) \\
6.8-4.3 \\
(3.2)^{3} \\
0.0-2.4 \\
(1.7)^{-4} \\
0.0-2.7 \\
(3.1)^{7} \\
5.0-3.8 \\
(2.6)\end{array}$ & $\begin{array}{l}(5.5) \\
4.8-3.4 \\
(3.4)^{4} \\
2.6-2.2 \\
(1.9)^{2} \\
4.3-3.2 \\
(3.2)^{2} \\
3.9-4.1 \\
(2.6)\end{array}$ & $\begin{array}{r}(5.8) \\
3.9-2) \\
(3.4) \\
2.2-2 . \\
(2.1) \\
3.8-3 . \\
(3.2) \\
4.1-3 . \\
(2.9)\end{array}$ & $\begin{array}{r}4.3-4 \\
i 3.4 \\
2.6-2 \\
i 2.2 \\
3.8-4 \\
i 3.4 \\
3.9-4 \\
i 2.9\end{array}$ & $\begin{array}{l}6.8-7.2 \\
(6.3)^{2} \\
4.3-4.8 \\
(3.4)^{8} \\
2.7-2.9 \\
(2.4)^{2} \\
4.1-2.9 \\
(3.4) \\
4.1-4.1 \\
(3.4)\end{array}$ & $\begin{array}{r}16 . \\
4.6- \\
13 . \\
2.9- \\
12 . \\
3.9- \\
(3 . \\
4.3- \\
43 .\end{array}$ & $\begin{array}{l}(7.2) \\
4.8-5.3 \\
(3.8)^{3} \\
2.9-4.1 \\
(2.6) \\
4.3-4.1 \\
(3.8) \\
4.3 .3 .9 \\
(3.2)\end{array}$ & $\begin{array}{r}17 . \\
5.1- \\
14 . \\
3.1- \\
12 . \\
4.4- \\
3 . \\
4.3- \\
13 .\end{array}$ & 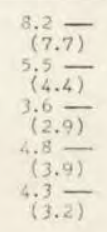 \\
\hline 6 & 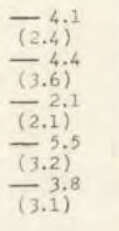 & $\begin{array}{l}4.1-3.8 \\
(2.6) \\
4.4-4.46 \\
(3.6) \\
3.4-1.5 \\
(2.1)^{5} \\
5.5-6.0 \\
(3.2) \\
3.8-6.7 \\
(3.1)\end{array}$ & $\begin{array}{l}(2.6) \\
4.4-4.4 \\
(3.8) \\
1.7-4.4 \\
(2.2) \\
5.8-6.5 \\
(3.2) \\
5.3-3.9 \\
(3.1)\end{array}$ & $\begin{array}{r}4.4-4.4 \\
(2.9 \\
4.4-4 \\
(3.9 \\
2.6-1 . \\
(2.2) \\
6.3-6.6 \\
(3.2) \\
4.6-5 . \\
(3.2 .\end{array}$ & 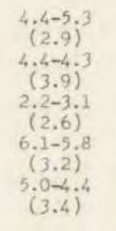 & $\begin{array}{r}13.4 \\
4.4-4 \\
13.9 \\
2.4-1 \\
12.6 \\
6.0-6 \\
13.2 \\
5.0-4 \\
13.4\end{array}$ & $\begin{array}{r}13 . \\
4.3- \\
13 . \\
2.2- \\
12 . \\
6.1- \\
13 . \\
5.0- \\
3 .\end{array}$ & $\begin{array}{l}4.8- \\
13 . \\
4.3- \\
13 . \\
2.4- \\
12 . \\
6.7- \\
13 . \\
5.0- \\
13 .\end{array}$ & $\begin{array}{l}4.3-4.3^{3} \\
(3.4)^{2} \\
4.3-3.8 \\
(3.9)^{2} \\
2.6-1.9 \\
(2.6) \\
6.8-7.0 \\
(3.6) \\
5.1-3.8 \\
(3.2)\end{array}$ & $\begin{array}{l}4.8 . \\
(3.4) \\
4.3 .3 \\
(3.9) \\
2.6 .5 \\
(2.6) \\
7.0 \frac{1}{(3.6)} \\
5.1-1) \\
(3.1)\end{array}$ \\
\hline 12 & 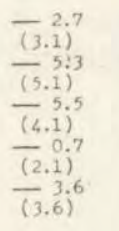 & $\begin{array}{l}2.7-3.2 \\
(3.1) \\
5.3 .7 .3 \\
(5.0)^{-3} \\
5.5-3.4 \\
(4.1)^{2} \\
0.7-1.4 \\
(2.1) \\
3.6-4.6 \\
(3.6)\end{array}$ & $\begin{array}{l}(3.1) \\
6.5-8.0 \\
(4.8) \\
3.6-5.3 \\
(4.1)^{3} \\
1.0-1.7 \\
(2.1) \\
4.3-3.6 \\
(3.6)\end{array}$ & $\begin{array}{r}3.1 \\
7.5-6 \\
i 5.0 \\
4.3-3 \\
i 4.1 \\
1.4-3 \\
i 2.1 \\
3.8-3 \\
i 3.6\end{array}$ & $\begin{array}{l}73 . \\
7.5- \\
15 . \\
4.1- \\
14 . \\
2.4- \\
12 . \\
3.8- \\
13 .\end{array}$ & $\begin{array}{l}(3.1) \\
7.2-6.5 \\
(4.8) \\
4.1-4.8 \\
(4.1)^{2} \\
2.6-1.9 \\
(2.1)^{9} \\
3.8-3.9 \\
(3.6)\end{array}$ & $\begin{array}{l}(3.2 . \\
7.0- \\
14.3- \\
4.34 . \\
2.2-1 \\
12 . \\
3.8- \\
13 .\end{array}$ & $\begin{array}{r}73 . \\
7.2- \\
14 . \\
4.6- \\
14 . \\
2.2 . \\
12 . \\
3.8 . \\
13 .\end{array}$ & $\begin{array}{l}(3.2) \\
7.2-6.3 \\
(4.8) \\
4.6-3.8 \\
(4.1) \\
2.6-2.1 \\
(2.1) \\
3.8-3.6 \\
(3.6)\end{array}$ & 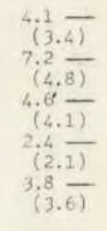 \\
\hline 16 & 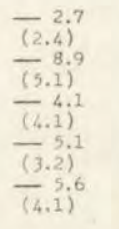 & $\begin{array}{l}2.7-2.9 \\
(2.4) \\
8.9-6.3 \\
(5.1) \\
4.4-3.4 \\
(3.9) \\
5.6-8.7 \\
(3.1) \\
6.1-4.1 \\
(4.1)\end{array}$ & $\begin{array}{l}2.9-2.9 \\
(2.4)^{2} \\
6.8-6.1 \\
(5.1) \\
4.4-3.6 \\
(3.9)^{-1} \\
9.2-5.8 \\
(3.1) \\
5.5-4.1 \\
(3.6)\end{array}$ & $\begin{array}{l}3.1-3 \\
12.4 \\
6.5-7 \\
15.1 \\
4.8-3 \\
13.8 \\
6.8-4 \\
12.9\end{array}$ & $\begin{array}{l}3.2-3 \\
12.4 \\
6.8-6 \\
i 5.1 \\
5.0-2 \\
13.8 \\
6.0-4 \\
i 2.9 \\
6.1-4 \\
13.8\end{array}$ & $\begin{array}{l}3.2-3 \\
i 2.2 \\
6.8-6 \\
i 5.1 \\
4.6-2 \\
i 3.8 \\
7.0-5 \\
i 3.1 \\
6.3-5 \\
i 3.8\end{array}$ & $\begin{array}{l}3.2-3 \\
12.7 \\
6.8- \\
i 5.8 \\
4.6-1 \\
i 3.8 \\
7.5-1 \\
3.4 \\
3.7-1 \\
13.6\end{array}$ & $\begin{array}{r}3.2-2 \\
12.2 \\
6.8-3 \\
i 5.0 \\
4.6-2 \\
i 3.2 \\
7.3-5 \\
i 3.4 \\
5.7-3 \\
i 3.6\end{array}$ & $\begin{array}{l}3.2-2.7 \\
(2.2)^{7} \\
6.8-5.0 \\
(5.0) \\
5.0-1.7 \\
(3.8)^{2} \\
7.5-4.6 \\
(3.1) \\
6.8-2.6 \\
(3.9)\end{array}$ & 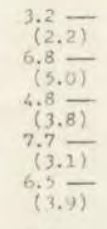 \\
\hline 21 & 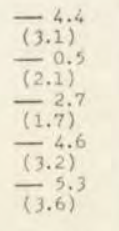 & $\begin{array}{l}4.8-4.6 \\
(2.9)^{6} \\
0.5-1.44 \\
(1.9) \\
2.7-2.2 \\
(1.7)^{2} \\
4.6-8.0 \\
(3.2) \\
5.5-3.2 \\
(3.2)\end{array}$ & $\begin{array}{l}5.0-2.9 \\
(3.1) \\
1.2-1.4 \\
(1.9)^{2} \\
2.4-2.44 \\
(1.5) \\
6.3-6.1 \\
(3.1) \\
4.1-3.1 \\
(3.1)\end{array}$ & $\begin{array}{l}3.8-2.6 \\
(2.7) \\
2.1-1.2 \\
(1.7) \\
2.7-1.9 \\
(0.9) \\
6.7-6.1 \\
(3.2) \\
3.9-3.1 \\
(2.9)^{2}\end{array}$ & $\begin{array}{l}3.8-1.9 \\
(2.6) \\
1.7-3.6 \\
(1.5) \\
2.7-1.4 \\
(0.9)^{2} \\
6.7-6.0 \\
(2.9) \\
3.9-2.6 \\
(2.9)^{2}\end{array}$ & $\begin{array}{l}3.6-2.2 \\
(2.4) \\
2.6-1.7 \\
(1.5) \\
2.6-1.0 \\
(0.7) \\
6.7-5.6 \\
(2.7) \\
3.9-2.1 \\
(2.6)\end{array}$ & $\begin{array}{l}3.6-1 . \\
(2.4) \\
2.7-1 . \\
(1.5 \\
2.6-1 \\
10.9 \\
6.8-5 \\
(2.9 \\
3.9-1 . \\
(2.2)\end{array}$ & $\begin{array}{l}3.8-3.8 \\
(2.4) \\
2.6-1.0 \\
(1.4) \\
2.7-0.9 \\
(0.7) \\
6.8-4.6 \\
(2.6) \\
3.9-1.9 \\
(2.2)\end{array}$ & $\begin{array}{l}4.1-1.4 \\
(1.9)^{2} \\
2.4-0.9 \\
(1.4)^{2} \\
2.6-1.5 \\
(0.7)^{2} \\
6.8-4.1 \\
(2.6) \\
3.9-1.5 \\
(2.1)^{2}\end{array}$ & $\begin{array}{l}4.1 \\
(1.7) \\
2.2 .7) \\
(1.4) \\
2.7 \\
(0.5) \\
6.8 \\
(1.9) \\
3.9 .9 \\
(1.7)\end{array}$ \\
\hline 26 & $\begin{array}{l}\frac{1.7}{(1.7)^{7}} \\
\frac{13.5}{(3.1)}\end{array}$ & $\begin{array}{r}1.7-1.5 \\
(1.5)^{5} \\
15.0-5.0 \\
(2.7)\end{array}$ & $\begin{array}{c}1.7-1.4 \\
(1.5) \\
7.7-3.4 \\
(2.4)\end{array}$ & $\begin{array}{l}1.7-1.2 \\
(0.9) \\
5.8-2.6 \\
(2.1)\end{array}$ & $\begin{array}{l}1.7-1.2 \\
(0.7)^{2} \\
5.1-3.2 \\
(1.7)^{2}\end{array}$ & $\begin{array}{l}1.9-1.4 \\
(0.7) \\
5.3-2.2 \\
(1.5)\end{array}$ & $\begin{array}{l}1.7-1.2 \\
(0.5) \\
5.3-1.9 \\
(1.4)^{2}\end{array}$ & $\begin{array}{l}1.7-1.2 \\
(0.5)^{2} \\
5.0-1.5 \\
(1.2)^{5}\end{array}$ & $\begin{array}{l}1.7-1.0 \\
(0.5) \\
5.0-1.5 \\
(1.0)^{2}\end{array}$ & $\begin{array}{l}1.7 \\
(0.3) \\
(0.9) \\
(0.9)\end{array}$ \\
\hline
\end{tabular}

(sometimes referred to as the Jolly-Seber estimator) has been examined rather carefully by Carothers (1973), Gilbert (1973), W i l bur \& Landwehr (1974) and Cameron (1977). Wilbur \& Landwe h r (1974 reported in to be the most efficient estimator available for 


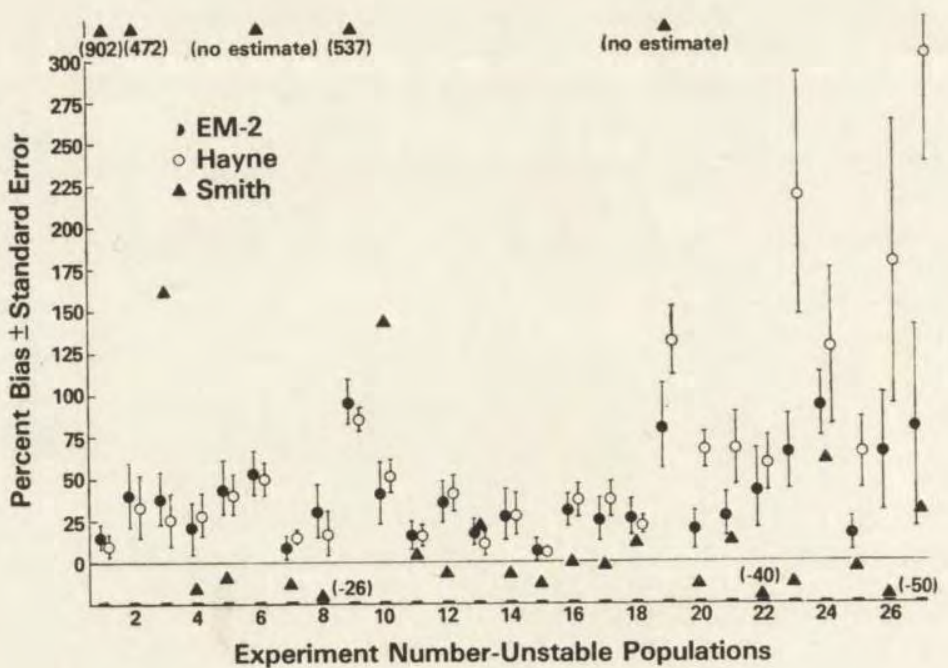

Fig. 4. Average percent biases and standard errors $(\alpha=.95)$ for the $E M-2$ (Jorgensen et al., 1975) and Hayne (1949) estimates of the unstable populations. Smith et al. (1971) percent biases include only one estimate and no standard error for each experiment since daily estimates are not possible. Perfect agreement with the actual density $=0$.

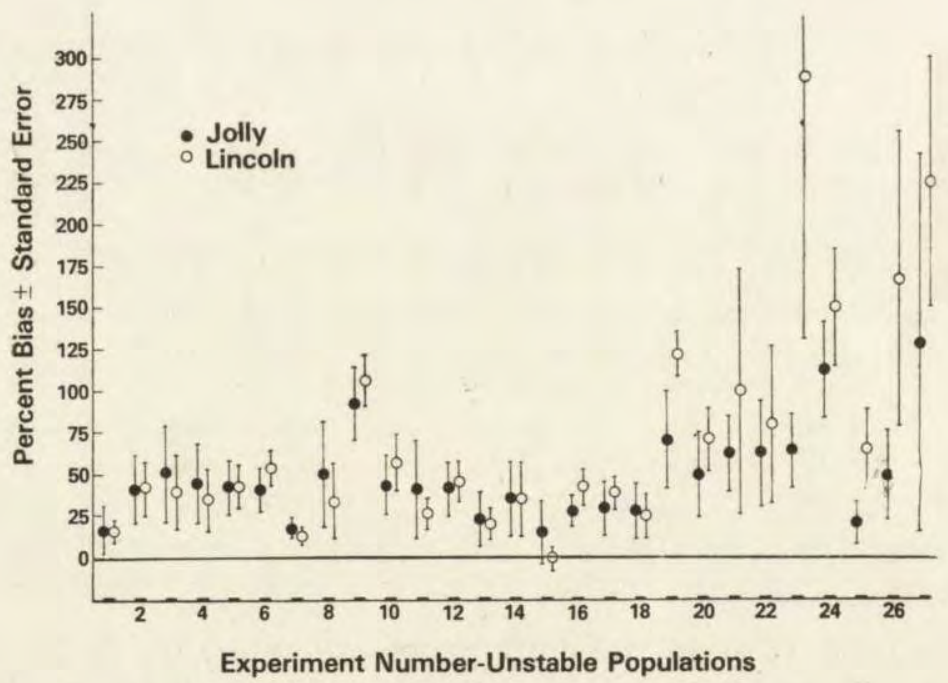

Fig. 5. Average percent biases and standard errors $(\alpha=.95)$ for the J oll y (1965) and Lincoln (1930) estimates of the unstable populations. Perfect agreement with the actual density $=0$. 
Table 5

Densities (animals per ha) for Lincoln's $\left(\mathbb{N}_{L}\right)$ and Jolly's $\left(\widehat{N}_{J}\right)$ estimation methods of simulated populations in which the numbers of animals were changing during the sampling period (see Table 7).

\begin{tabular}{|c|c|c|c|c|c|c|c|c|c|c|}
\hline \multicolumn{11}{|c|}{ Estimatea for Each Trapping Day $-N$ in Parentheses } \\
\hline & 1 & 2 & 3 & 4 & 5 & 6 & 7 & 8 & 9 & 10 \\
\hline & $\left.\bar{i}_{(L)}\right)_{(N)}^{-\hat{N}}(J)$ & $\tilde{N}_{\left(L L_{(N)}^{-\hat{N}}(J)\right.}$ & $\left.\hat{n}_{(L L)}\right)_{(N)^{-\hat{N}}(J)}$ & $\hat{N}_{\left(L t_{N}\right)^{-n}(J)}$ & $\left.\hat{i}_{(L)}\right)_{(N)}^{-\hat{N}_{S}}$ & $\dot{u}_{(L)}-\hat{n}(v)$ & $\left.\hat{u}_{(L)}\right)_{(N)}^{-\hat{n}}(v)$ & $\left.\bar{y}_{(L)}\right\}_{(N)}^{-\tilde{N}}(s)$ & $\left.\hat{n}_{(L)}\right)_{(N)}^{-\hat{n}_{(I)}}$ & $\bar{i}_{(L)}(u)-\hat{N}_{(j)}$ \\
\hline \multirow{6}{*}{3} & $\overline{(5,1)}$ & \multirow{5}{*}{$\begin{array}{l}5.6-5.1 \\
(5.3) \\
6.0-6.1 \\
(3.2)^{2} \\
0.0-0.0 \\
(1.7) \\
0.0-0.0 \\
(3.1) \\
5.0-5.0 \\
(2.6)\end{array}$} & \multirow{6}{*}{ 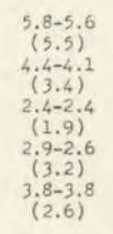 } & \multirow{6}{*}{$\begin{array}{l}7.2-6.8 \\
(5.8) \\
3(6-3.2 \\
(3.4) \\
2.2-2.4 \\
(2.1) \\
3.4-3.8 \\
(3.2) \\
4.1 .24 .4 \\
(2.9)\end{array}$} & \multirow{6}{*}{$\begin{array}{l}7.0-6.8 \\
(6.0) \\
4.6-4.8 \\
(3.4)^{8} \\
2.9-2.6 \\
(2.2)^{2} \\
3.6-2.1 \\
(3.4)^{-1} \\
3.8-3.4 \\
(2.9)^{2}\end{array}$} & \multirow{6}{*}{$\begin{array}{l}7.0-7.2 \\
(6.3) \\
4.3-3-3.3 \\
(3.4) \\
3.1-3.3 .2 \\
(2.4) \\
4.6-4.3 \\
(3.4)^{3} \\
4.6-4.4 \\
(3.4)\end{array}$} & \multirow{5}{*}{$\begin{array}{l}7.3-7.5 \\
(6.5) \\
5.3-5.5 \\
(3.5) \\
3.1-2.7 \\
(2.6) \\
3.4-4.8 \\
(3.4) \\
4.4-3.9 \\
(3.2)\end{array}$} & \multirow{5}{*}{$\begin{array}{l}9.4-8.2 \\
(7.2)^{2} \\
5.8-6.8 \\
(3.8) \\
2.9-5.5 \\
(2.6)^{5} \\
5.1-2.1 \\
(3.8) \\
4.3-4.3 \\
(3.2)^{3}\end{array}$} & \multirow{5}{*}{$\begin{array}{l}9.4-12.8 \\
(7.5) \\
6.1-4.6 \\
(4.3) \\
5.1-5.5 \\
(2.9)^{2} \\
6.0-0.0 \\
(3.8) \\
4.3-4.1 \\
(3.2)\end{array}$} & \multirow{6}{*}{$\begin{array}{l}9.2 .7 \\
(7.7) \\
7.0 .4) \\
(4.4) \\
5.1 .9) \\
(2.9) \\
6.19) \\
(3.9) \\
4.6 .9 \\
(3.2)\end{array}$} \\
\hline & $(3.1)$ & & & & & & & & & \\
\hline & $(1.7)$ & & & & & & & & & \\
\hline & 12.7 & & & & & & & & & \\
\hline & (3.1) & & & & & & & & & \\
\hline & (2.4.4 & \multirow{7}{*}{$\begin{array}{l}4.1-3.4 \\
(2.6)^{2} \\
4.4-6.4 \\
(3.6) \\
2.1-1.4 \\
(2.1)^{-4} \\
5.5-5.5 \\
(3.2)^{-5} \\
3.8-3.8 \\
(3.1)\end{array}$} & & & & & \multirow{7}{*}{$\begin{array}{l}4.8-4.0 \\
(3.4)^{0} \\
4.3-4.6 \\
(3.9)^{2} \\
1.92-2.1 \\
(2.6) \\
7.2-7.5 \\
(3.6)^{2} \\
5.3-3.3 \\
(3.4)^{3}\end{array}$} & \multirow{7}{*}{$\begin{array}{l}4.8-5.0 \\
(3.4) \\
4.3-4.4 \\
(3.9)^{-4} \\
2.9-2.1 \\
(2.6)^{2} \\
8.7-8.9 \\
(3.6) \\
5.5-4.1 \\
(3.2)\end{array}$} & \multirow{7}{*}{$\begin{array}{l}4.8-3.8 \\
(3.4)^{2} \\
4.3-3.4 \\
(3.9) \\
3.4-2.9 \\
(2.6) \\
7.3-5.8 \\
(3.6) \\
5.6-5.6 \\
(3.2)\end{array}$} & \\
\hline \multirow{6}{*}{$\begin{array}{l}\cdot \\
7 \\
10\end{array}$} & $\overline{(2.4)}$ & & \multirow{6}{*}{$\begin{array}{l}5.0-4.4 \\
(2.6) \\
4.6-4.6 \\
(3.8) \\
1.5-1.4 \\
(2.2)^{-4} \\
6.0-6.0 \\
(3.2) \\
6.8-6.0 \\
(3.1)\end{array}$} & \multirow{6}{*}{$\begin{array}{l}4.3-3.9 \\
(2.9)^{2} \\
4.4-4.4 \\
(3.9)^{4} \\
4.8-5.3 \\
(2.2)^{3} \\
6.7-7.0 \\
(3.2) \\
4.1-3.9 \\
(3.2)\end{array}$} & \multirow{6}{*}{$\begin{array}{l}4.6-4.4 \\
(2.9)^{4} \\
4.4-4.44 \\
(3.9) \\
1.7-1.4 \\
(2.6)^{2} \\
5.8-6.0 \\
(3.2) \\
5.3-5.0 \\
(3.4)\end{array}$} & \multirow{6}{*}{$\begin{array}{l}5.3-4.8 \\
(3.4)^{2} \\
4.3-4.1 \\
(3.9) \\
3.4-5.1 \\
(2.6)^{2} \\
5.8-5.5 \\
(3.2) \\
5.0-5.1 \\
(3.4)\end{array}$} & & & & \multirow{6}{*}{$\begin{array}{l}4.8 .5 \\
(3.4) \\
4.3 .5 \\
(3.9) \\
2.4 .6 \\
(2 ., 6) \\
7.9 .6 \\
(3.6) \\
5.1 \\
(3.1)\end{array}$} \\
\hline & $(3.6)$ & & & & & & & & & \\
\hline & (1) & & & & & & & & & \\
\hline & $(2.1)$ & & & & & & & & & \\
\hline & (3.2) & & & & & & & & & \\
\hline & (3.1) & & & & & & & & & \\
\hline \multirow[t]{2}{*}{11} & $(3.1)$ & \multirow{6}{*}{$\begin{array}{l}2.7-2.4 \\
(3.1) \\
5.3 .50 \\
(5.0) \\
5.5-6.8 \\
(4.1) \\
0.7-0.7 \\
(2.1) \\
3.6-3.6 \\
(3.6)\end{array}$} & \multirow{6}{*}{$\begin{array}{l}3.4-3.8 \\
(3.1) \\
7.5 .6 .5 \\
(4.8) \\
3.43 .1 \\
(4.1 .1 \\
1.4-1.4 \\
(2.1)^{2} \\
4.6-4.6 \\
(3.6)\end{array}$} & \multirow{6}{*}{$\begin{array}{l}4.1-3.6 \\
(3.1)^{2} \\
8.5-7.9 \\
(5.0) \\
5.5-4.8 \\
(4.1 .8 \\
1.7-2.1 \\
(2.1)^{2} \\
3.6-3.6 \\
(3.6)\end{array}$} & \multirow{6}{*}{$\begin{array}{l}3.8-3.6 \\
(3.1)^{2} \\
7.5-6.7 \\
(5.0)^{2} \\
4.1-3.2 \\
(4.1)^{2} \\
3.6-3.4 \\
(2.1)^{-4} \\
3.6-3.6 \\
(3.6)\end{array}$} & & $\begin{array}{r}3.9-4 \\
i 3.2\end{array}$ & $\begin{array}{r}5.0-7 \\
(3.2\end{array}$ & & $5.0-\overline{(3)}$ \\
\hline & (3.1) & & & & & $6.5-6$ & $7.0-6$ & $7.7-$ & & \\
\hline 13 & $(5.1)$ & & & & & $3.6-2$ & $5.5-4$ & $5.1-$ & & 4.4. \\
\hline & (4.1) & & & & & & & (4. & & (4. \\
\hline & (2.1) & & & & & $(2.1)$ & & $(2$ & 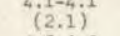 & $(2.3)$ \\
\hline 15 & (3.6) & & & & & (3.9-1. & & $\begin{array}{l}3.8 . \\
(3 .\end{array}$ & & $3.8 \overline{(3.6)}$ \\
\hline 16 & $\overline{(2.4)}$ & $\begin{array}{l}2.7-2.4 \\
(2.4)\end{array}$ & & & & & & & & \\
\hline 17 & (5.1) & $\begin{array}{c}8.9-9.2 \\
(5.1)^{2}\end{array}$ & $\begin{array}{c}6.5-6.5 \\
(5.1)^{5}\end{array}$ & 6.1- & $\begin{array}{c}7.5-7.3 \\
(5.1)^{3}\end{array}$ & $\begin{array}{l}6.8-6.8 \\
(5.1)\end{array}$ & & $\begin{array}{l}6.5 \\
15\end{array}$ & & $(5.7)$ \\
\hline & 0.11 & $4.4-4.11$ & $4.4-2,1$ & $5.5-2$ & $5.5-$ & 3.9- & 5.0. & & & 4.4. \\
\hline 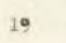 & $(4.1)$ & $5.6-5.5$ & $7.3-7.0$ & $7.0-$ & & & & & & 7.5 . \\
\hline$n$ & $(3.2)$ & & $\begin{array}{r}13.1 \\
5.1-4\end{array}$ & & & 6.5. & & & & 5.1. \\
\hline & $(4.1$ & & & & & & & & & 3.97 \\
\hline a & $\overline{(3.1)}$ & & $\begin{array}{l}5.1-5.6 \\
(3.1)^{6}\end{array}$ & & & $\begin{array}{l}2.9-1 \\
12.4\end{array}$ & & & & 涼. \\
\hline & (2.1) & & $\begin{array}{l}1.4-1 \\
(1.9\end{array}$ & i1. & & (1.5- & i. & & & (1. $1 . \overline{4}$ \\
\hline & (1.7) & $\begin{array}{l}2.7-3.4 \\
(1.7)^{4}\end{array}$ & $\begin{array}{c}2.4-0.0 \\
(1.5)\end{array}$ & $\begin{array}{l}3.1-1- \\
i 0 .\end{array}$ & & $\begin{array}{l}2.2-0 \\
i 0.7\end{array}$ & $\begin{array}{l}2,2-1 \\
10 .\end{array}$ & $\begin{array}{l}4.4- \\
10 .\end{array}$ & & $48.5)$ \\
\hline & $(3.2)$ & $\frac{4.6-4.3}{(3.2)^{3}}$ & $\begin{array}{l}8.5-7.9 \\
(3.1)^{9}\end{array}$ & $\begin{array}{l}6.7- \\
\text { i3. }\end{array}$ & & $\begin{array}{r}6.8-7 \\
(2.7\end{array}$ & $\begin{array}{l}7.0- \\
12 .\end{array}$ & $\begin{array}{r}7.3- \\
i 2 .\end{array}$ & & (1.8) \\
\hline & $(3.6)$ & & $\begin{array}{l}3.6-3.9 \\
(3.1)\end{array}$ & & & $\begin{array}{r}3.8-2 \\
i 2.6\end{array}$ & $\begin{array}{l}3.8- \\
(2 .\end{array}$ & & $\begin{array}{l}4.4-2.2 \\
(2.1)^{2}\end{array}$ & (1.7) \\
\hline 20 & $\overline{10}, 7$ & $(1,5)$ & $1.7-2.4$ & 10.9 & & & & & & $3.7 . \overline{3}$ \\
\hline & & $\begin{array}{c}15.0-17.7 \\
(2.7)\end{array}$ & $\frac{6.1-4.6}{(2.4)^{6}}$ & $\begin{array}{l}4.8-3.6 \\
(2.1)\end{array}$ & & & & & & \\
\hline
\end{tabular}

use wnen capture mistories or inaiviauais are known, ana many presently consider it still the best.

The field design $(D S-R)$ performed precisely as S mith et al. (1971) predicted and demonstrated it would, i.e. trapping on the grid created 
the essential void and assessment lines provided data that could be used to determine an estimate of void's size and subsequently the density of animals on the grid. The design provided for areas of complete

Table 6

Estimates and densities of animal numbers using $\mathrm{Smith}$ et al.'s (1971) removal method $(E M-R)$ in which the numbers were changing during the sampling period (see Table 3).

\begin{tabular}{|c|c|c|c|c|c|c|c|}
\hline \multirow[b]{2}{*}{$\begin{array}{l}\text { Experiment } \\
\text { Nunber }\end{array}$} & \multicolumn{3}{|c|}{ Grid Area ( $5.86 \mathrm{ha})$} & \multicolumn{4}{|c|}{ Complete Renoval Area } \\
\hline & $\begin{array}{l}\text { Maximum No. } \\
\text { of Animals }\end{array}$ & $\begin{array}{l}\text { Animal } \\
\text { Density }\end{array}$ & $\begin{array}{l}\text { No. of Animals } \\
\text { Removed }\end{array}$ & $\begin{array}{l}\text { Size of } \\
\text { Area, has }\end{array}$ & Actual & $\begin{array}{l}\text { Densiciesa } \\
\text { Eatimated ( } B M\end{array}$ & $(-R)$ \\
\hline $\begin{array}{l}1 \\
2 \\
3 \\
4 \\
5\end{array}$ & $\begin{array}{l}45 \\
27 \\
17 \\
27 \\
21\end{array}$ & $\begin{array}{l}7.68 \\
4.61 \\
2.90 \\
4.61 \\
3.58\end{array}$ & $\begin{array}{l}49 \\
39 \\
17 \\
24 \\
26\end{array}$ & $\begin{array}{l}2.16 \\
3.28 \\
2.22 \\
6.66 \\
8.47\end{array}$ & $\begin{array}{l}2.31 \\
2.13 \\
0.45 \\
4.50 \\
3.54\end{array}$ & $\begin{array}{r}23.15 \\
12.20 \\
7.66 \\
3.75 \\
3.19\end{array}$ & \\
\hline $\begin{array}{r}6 \\
7 \\
8 \\
9 \\
10\end{array}$ & $\begin{array}{l}21 \\
24 \\
14 \\
22 \\
21\end{array}$ & $\begin{array}{l}3.58 \\
4.10 \\
2.39 \\
3.75 \\
3.58\end{array}$ & $\begin{array}{l}26 \\
33 \\
13 \\
50 \\
37\end{array}$ & $\begin{array}{l}1.85 \\
9.18 \\
7.18 \\
3.69 \\
4.97\end{array}$ & $\begin{array}{l}-6 \\
4.90 \\
2.65 \\
2.17 \\
3.22\end{array}$ & $\begin{array}{r}11.05 \\
3.59 \\
1.95 \\
13.82 \\
7.65\end{array}$ & \\
\hline $\begin{array}{l}11 \\
12 \\
13 \\
14 \\
15\end{array}$ & $\begin{array}{l}21 \\
35 \\
24 \\
12 \\
21\end{array}$ & $\begin{array}{l}3.58 \\
5.97 \\
4.10 \\
2.05 \\
3.58\end{array}$ & $\begin{array}{l}25 \\
47 \\
28 \\
12 \\
32\end{array}$ & $\begin{array}{l}6.66 \\
7.62 \\
6.45 \\
6.10 \\
9.18\end{array}$ & $\begin{array}{l}3.90 \\
6.82 \\
4.03 \\
2.13 \\
4.24\end{array}$ & $\begin{array}{l}4.05 \\
6.30 \\
4.65 \\
1.97 \\
3.59\end{array}$ & , \\
\hline $\begin{array}{l}16 \\
17 \\
18 \\
19 \\
20\end{array}$ & $\begin{array}{l}14 \\
30 \\
24 \\
29 \\
36\end{array}$ & $\begin{array}{l}2.39 \\
5.21 \\
4.10 \\
4.95 \\
6.14\end{array}$ & $\begin{array}{l}24 \\
46 \\
30 \\
44 \\
28\end{array}$ & $\begin{array}{l}7.24 \\
7.90 \\
6.10 \\
1.93 \\
7.18\end{array}$ & $\begin{array}{l}3.31 \\
6.08 \\
4.75 \\
5.29\end{array}$ & $\begin{array}{r}3.31 \\
5.95 \\
5.25 \\
23.32 \\
4.32\end{array}$ & \\
\hline $\begin{array}{l}21 \\
22 \\
23 \\
24 \\
25\end{array}$ & $\begin{array}{l}27 \\
14 \\
12 \\
22 \\
21\end{array}$ & $\begin{array}{l}4.61 \\
2.39 \\
2.05 \\
3.75 \\
3.58\end{array}$ & $\begin{array}{l}19 \\
11 \\
14 \\
46 \\
29\end{array}$ & $\begin{array}{r}5.62 \\
12.53 \\
7.24 \\
6.10 \\
8.35\end{array}$ & $\begin{array}{l}3.20 \\
1.60 \\
2.21 \\
4.75 \\
3.59\end{array}$ & $\begin{array}{l}3.56 \\
0.96 \\
2.93 \\
7.54 \\
3.47\end{array}$ & \\
\hline $\begin{array}{l}26 \\
27\end{array}$ & $\begin{array}{l}10 \\
18\end{array}$ & $\begin{array}{l}1.71 \\
3.07\end{array}$ & $\begin{array}{l}13 \\
30\end{array}$ & $\begin{array}{r}13.54 \\
6.66\end{array}$ & $\begin{array}{l}1.92 \\
3.45\end{array}$ & $\begin{array}{l}0.96 \\
4.50\end{array}$ & \\
\hline
\end{tabular}

a Acres less than 5.86 ha indicate that the grid area was not completely trapped out leaving the estimate in considerable doubt, usually too high to be realistic.

b The area of complete removal was so small that animals were not found strictly within the area, leaving the estimate entirely too high.

removal, partial removal and no removal in estimating the densities. Although this study computed estimates of population densities (Table 1), the area of partial removal did not materialize when stable populations were sampled, even though it was expected since the simulated animals could not shift their centers of activity and did not range beyond the home range radii specified in Table 2 . Under natural conditions, the area of partial removal would still be expected to develop, but primarily as animals shift their home ranges, either by moving the activity center or ranging further in response to the created voids; otherwise 
this area would be negligible or virtually eliminated. Since the S m ith et al. (1971) method of assessing densities depends on stable home ranges, it can be challenged, but only as it relates to the size of area of complete removal; and even then the results for stable populations seems adequate and better than most live-trapping field designs (Fig. 2 and 3 ).

If a population is not stable and particularly if birth and death are responsible for the instability, it is helpful to have an estimator that will provide some information about what is happening to the population during the trapping period. Because of this EM-R was not particularly while sampling unstable populations. When a population was experiencing substantial loss through death, as in experiments $19-27$ (Table 3 ), the void was created, but fewer animals were removed than expected. Consequently, when the data from the assessment lines were used to determine the void size, animals were caught somewhat further from the grid and the densities were often underestimated (Table 6). This phenomena is compensated for when: (1) the animals are essentially removed during the first 3-4 days of trapping, (2) the death rate is not particularly high or (3) birth and death are occurring simultaneously during the trapping period.

When birth (at least entrance into the trappable population) is high (Table 3), there would be a tendency to underestimate the population since the void would be expected to be smaller (Fig. 4). As one examines results on Tables $5-6$ and Fig. 4, relative average void sizes can be determined as: death only -8.30 ha, stable -7.24 ha, birth and death $6.4 \mathrm{ha}$, and birth only -4.62 . This is precisely what one would expect, although unstable populations, particularly those experiencing birth and death, may vary considerably relative to one another, depending on which parameter is dominant. Where death is dominant (Experiments $22-24$ ) or birth is dominant (Experiments $4-6$ ), the average void sizes are 5.78 ha for birth dominance and 8.60 ha for death dominance - again precisely what would be expected. Since there was a distinct area of partial removal in unstable populations, this phenomenon alone might indicate that stability is not satisfied in natural populations if a similar area of partial removal is made, although it does not indicate the cause of instability.

Since $(N-N)^{2}$ can be used to assess the relative accuracy of an estimate, some comparisons will be helpful in visualizing how home range radii and densities affect the density estimates. If activity radii are relatively small, the encroachment of periphery animals into the void is negligible, as is the case with small densities; thus, these will consistently underestimate the actual densities. The opposite is true 
for large radiı and high densities. These observations are expected since they have direct impacts on the void. In stable populations the average $(N-N)^{2}$ for radii equal to $30 \mathrm{~m}$ was $0.240,0.752$ for radii equal to $44 \mathrm{~m}$ and 1.977 for radii equal to $54 \mathrm{~m}$. Similarly, when contrasting the results of varying densities, i.e. 100 animals provided an average $(\bar{N}-N)^{2}$ of 0.495 , while 200 provided 0.276 and 300 provided 2.054. This suggests that densities too low or too high might produce less reliable results.

Data gathered from the unstable populations produced similar results, although they were further confounded by varying birth and death rates. As the home range radii increased from $30-44-54,(\mathbb{N}-N)^{2}$ increased from 0.383-66.634-98.498, respectively; while the same estimates for densities of 67,133 and 200 animals per ha produced 27.963, 13.831 and 124.833 , respectively. Again, it appears that if densities are too low or too high, the S $\mathrm{mith}$ et al. (1971) method may produce questionable results, particularly when the population is unstable.

Live trapping results are somewhat easier to contrast since the population parameters and actual densities were constant for each experiment. The $D S-L$ design (Jorgensen et al., 1972) was demonstrated to be an improvement over other previously used designs. The dense-line provided a method that limited the area of effect to the grid, reduced the border effect and limited dispersal by partitioning animals into grid and non-grid residents. Although it was originally thought that the dense-line would allow measurements of dispersal, it often inhibited movement (F ren ch et al., 1971) and what discernable dispersal occurred resulted from random fluctuations, but there is still reason to think the dense-line can serve in its original function if dispersal is important during the trapping period. The most essential consideration in placing the dense-line is to insure it is not too far from the grid (Fig. 1) to allow animals mid-way between the grid and denseline to conveniently reach each.

A brief examination of Table 1 and Fig. 2 and 3 illustrate that EM-2 generally performs better than the other live-trapping estimators for 10 day periods. If it is necessary to trap for less than five days and a stable population can be assumed, H a y n e's (1949) $\left(\hat{N}_{(H)}\right)$ estimator will approach $N$ more rapidly and can be expected to produce better estimates earlier in the analyses.

As was mentioned earlier, if the populations are unstable during the trapping period, it is important to get as much information about the changes as possible. Among these estimators, only $\hat{N}_{(J)}$ and $E M-2$ were capable of responding appropriately to death in the population during the trapping period, although $\hat{N}_{(L)}$ and $\hat{N}_{(H)}$ were sensitive to animals recruited into the population via birth. Although both $\hat{N}_{(J)}$ 
and EM-2 provided some indication of what the population experienced during the trapping period, $\hat{N}_{(J)}$ provided only survival and dilution rates, while $E M-2$ provided:

$\mathrm{Pa}_{i}=$ the probability of avoiding the traps for $i-1$ days before being caught, and

$P l_{i}=$ the probability that an animal left the grid during $i-1$ days.

These statistics generally provide for a better estimate of $N$ (Tables 1 , 4 and 5) when the individual daily estimates are considered. Also, if the average density estimates are considered, $E M-2$ provided a higher level of precision (Fig. 2-5).

General analyses of these results and inferences suggest that ecologists need to carefully evaluate their specific needs and establish an acceptable margin of error before selecting a trapping design and estimator. If one has information about population characteristics such as birth and death rates, dispersal behavior, activity radii, etc., better selections can be made; but if this information is unavailable a more robust estimator will provide the most reliable information. In this regard, $D S-2$ and $E M-2$ provide the best methods since they are always reliable, providing the dense line is close enough to the grid. Removal trapping $(D S-R)$ may also provide reliable estimates $(E M-R)$ if the area of partial removal is not too great. If this area is large, one would logically assume the population to be unstable, but since the analyses succeeds removal trapping, opportunities for adjustements and retrapping are not available.

Acknowledgement: We are grateful to Brigham Young University, that provided the means for developing the small mammal simulator to generate the comparative data.

\section{REFERENCES}

1. B a il e y N. T. J., 1952: Improvements in the interpretation of recapture data. J. Anim. Ecol. 21: 120-127.

2. Burge J. R. \& Jorgensen C. D., 1972: Home range of small mammals: a reliable estimate. J. Mammal. 54: 483-488.

3. Burnham K. P. \& Overton W. S., 1969: A simulation study of live trapping and estimation of population size. Ore. State Univ. Tech. Rpt. No. 14: $152 \mathrm{pp}$.

4. Cameron G. N., 1977: Validation of temporary removal trapping and extension to a two-species system. J. Mammal, 58: 78-83.

5. Carothers A. D., 1973: The effects of unified catchability of Jolly-Seber estimates. Biometrics 29: 79-100.

6. Fisher R. A. \& Ford E. B., 1947: The spread of a gene natural conditions in a colony of the moth Panaxia dominu'a L. Heredity 1: 143-147.

7. French N. R. Jorgensen C. D. Smith M. A. \& Maza B. G., 1971: Comparison of some IBP population estimation methods for small mammals. US-IBP Special Rpt.: 25 pp. 
8. Gilbert R. O., 1973: Approximations of the bias in the Jolly-Seber capturerecapture model. Biometrics 29: $501-526$.

9. Gromadski M. \& $\mathrm{Trojan}$ P., 1971: Estimation of population density in Microtus arvalis (Pall.) by three different methods. Ann. Zool. Fennici 8: $54-59$.

10. Hayne D. W., 1949. Two methods for estimating population from trapping records. J. Mammal. 30: 399-411.

11. Jorgensen C. D., Smith H. D. \& Scott D. T., 1972: Evaluation of techniques for estimating population sizes of desert rodents. US-IBP Desert Biome Rpt. 9007-06:383 pp.

12. Jorgensen C. D., Smith H. D. \& Scott D. T., 1975: Small mammal estimates using recapture methods, with variables partitioned. Acta theriol. 20: $303-318$

12. Jo11y G. M., 1963: Estimates of population parameters from multiple recapture data with death, and dilution-deterministic model. Biometrika 50 . $113-128$.

14. Jo11y G. M., 1965: Explicity estimates from capture-recapture data with both death and immigration-stochastic model. Biometrika 52: 225-247.

15. Kaufman D. W., Smith G. C., Jones R. M., Gentry J. B. \& S mith M. H., 1971: Use of assessment lines to estimate density of small mammals. Acta theriol. 16: 127-147.

16. Leslie P. H., 1952: The estimation of population parameters obtained by means of the capture-recapture method II. The estimation of total members. Biometrika 39: 363-388.

17. Leslie P. H. \& Chitty D., 1951: The estimation of population parameters from data obtained by means of the capture-recapture method $\mathrm{I}$. The maximum likelihood equations for estimating the death-rates. Biometrika 38: 269-292.

18. Lincoln F. C., 1930: Calculating water fowl abundance on the basis of banding returns. U.S.D.A. Cir. No. 118:4 pp.

19. Man ly B. F. J., 1970: A simulation study of animal population estimation, using the capture-recapture method. J. Appl. Ecol. 71: 13-39.

20. Man1 y B. F. J. \& P a r r M. J., 1968: A new method of estimating population size, survivorship, and birth rate from capture-recapture data. Trans. British Entomol. Soc. 18: 81-89.

21. Myl1ymäki A., Paasikal1io A. \& Häkkinen U.. 1971: Analyses of standard trapping of Microtus agrestis (L.) with triple isotope marking outside the quadrat. Ann. Zool. Fennici 8: 22-34.

22. Overton A. S. \& Davis D. E., 1969: Estimating the numbers of animals in wildlife populations [In: »Wildlife management techniques«, 3rd ed., ed. R. H. Giles, Jr.]. The Wildlife Soc.: 403-455.

23. Pelikán J., 1971: Calculated densities of small mammals in relation to quadrat size. Ann. Zool. Fennici 8: 3-6.

24. Petersen C. G. J., 1896: The yearly immigration of young plaice in the Limjord from the German Sea. Rpt. Danish Biol. Stat. 6: 1-48.

25. Ryszkowski L., 1971: Estimation of small rodent density, with the aid of colored bait. Ann. Zool. Fennici 8: 8-13.

26. Schnabel Z. E., 1938: The estimation of the total fish population of a lake. Am. Math. Monthly 45: $384-352$.

27. Scott D. T., 1973. Comparison of live and removal trapping for small mammals. Master's Thesis, Brigham Young Univ., Provo, Utah: $82 \mathrm{pp}$. 
28. Se ber G. A. F., 1965: A note on the multiple-recapture census. Biometrika 52: $249-259$.

29. Smith H. D., Jorgensen C. D. \& Tolle y H. D., 1972: Estimation of Small mammals using recapture methods: partitioning of estimator variables. Acta theriol. 17: 57-66.

30. Smith M. H., Blessing R., Chelton J. G., Gentry J. B., Golley F. \& Mc Ginnis J. T., 1971: Determining density for small mammal populations using a grid and assessment lines. Acta theriol. 16: 105-125.

31. Sw if t D. M. \& Steinhorst R. K., 1976: A technique for estimating small mammal population densities using a grid and assessment lines. Acta theriol. 21: $471-480$.

Accepted, October 15, 1977.

Del T. SCOTT, Clive D. JORGENSEN i H. Duane SMITH

\section{POROWNANIE OCEN ZAGĘSZCZENIA POPULACJI DROBNYCH SSAKOW, UZYSKANYCH METODAMI WYŁOWU I CMR}

\section{Streszczenie}

Zbadano wartość i wrażliwość powszechnie używanych estymatorów populacyjnych proponowanych przez Lincolna (1930), H a y ne'g o (1949), J olly'e go (1965), S mitha et al. (1971) i S mitha et al. (1972). W tym celu użyto danych z symulowanych populacji drobnych ssaków, z których pobierano określone próby, zmieniając podstawowe parametry populacyjne jak zagęszczenie i aktywność (we wszystkich klasach wieku) oraz tempo urodzeń i śmierci i badając wrażliwość estymatorów na skrajne ale zdarzające się w naturze zmiany tych parametrów (Tabela 1-3). Przeprowadzono 18 eksperymentów przy stałym zagęszczeniu i 27 $\mathrm{z}$ różnym tempem urodzeń i śmierci, prowadzących do zmian w zagęszczeniu. Dla szacowania zagęszczenia symulowanych populacji mierzonego metodami $C M R$ najlepsze są estymatory proponowane przez Haynego i Jorgensena et al. (1972), ale można też stosować indeks Lincolna. W warunkach naturalnych, kiedy nie można z góry przewidzieć zmian parametrów populacyjnych najpewniejszym estymatorem dla opracowania danych uzyskanych metodą CMR jest estymator Jorgensena et al., a dla danych pochodzących ze stosowania pułapek zabijających estymator Smitha et al. (Ryc. 2, 3). Ten ostatni zmienia się jednak znacznie wraz ze zmianą liczebności populacji w czasie odłowów. Wszystkie sprawdzone estymatory mają tendencje do zawyżania aktualnej liczebności (Tabela 4, 5; Ryc. 4, 5). Najmniejszym błędem tego rodzaju obarczony jest estymator $\mathrm{S} \mathrm{mith}$ a et al. (1971).

Reasumując: jeżeli populacja jest niezmienna w czasie odłowów, ocena $\mathrm{H}$ a y n e'g o (1949) jest najlepsza, a metoda Smitha et al. (1971) jest najdokładniejsza dla odłowów w pupałki zabijające. Natomiast jeżeli populacja w czasie pobierania prób jest zmienna, oceny Jolly'ego (1965) i Smitha et al. (1971) są całkowicie błędne. Najodpowiedniejszą metodą oceny zagęszczenia, jeżeli jej stałości nie znamy lub wiemy o istnieniu zmian w czasie odłowów jest metoda $E M-2$ (S mith et al., 1972). 